


\title{
Regulation of advocacy profession: global trends
}

\author{
DOI: https://doi.org/10.46398/cuestpol.3969.43
}

\author{
Tetiana Vilchyk* \\ Alla Sokolova ** \\ Tetiana Demchyna ***
}

\begin{abstract}
The objective of the article is to analyze the regulation of the legal profession and its global trends. There are many different types of regulators globally, and many different sources and methods of regulation. There is no simple approach to setting goals for regulating the legal profession in different legal systems. Although self-regulation of the legal profession is considered the basis for adhering to the standard of its independence, at the same time, academics recognize the existence of the theory of the management of the legal profession. To study these problems, the authors conducted a comparative study of the regulatory models of the legal profession in the world in terms of compliance with international standards of legal independence in different legal jurisdictions and made some suggestions to improve the legal regulation of the legal profession in Ukraine. Empirical sources for scientific research were international documents, court decisions, national legislation of Great Britain, Canada, the United States, Ireland, Scotland, Australia and others, and the work of scientists. The article uses general scientific methods - dialectic, analysis, synthesis, analogy, etc., and special methods, particularly legal, historical,
\end{abstract} and formal comparative law.

Keywords: association of defenders; regulation of the defense; independence of defense; autonomous associations of defenders; regulation of the legal profession.

\footnotetext{
* Doctor of Law, Professor. Yaroslav Mudryi National Law University. Ukraine. ORCID ID: https:// orcid.org/oooo-0002-0759-4935. Email: global@ores.su

** Doctor of Law, Associate Professor. Yaroslav Mudryi National Law University. Ukraine. ORCID ID: https://orcid.org/oooo-0o02-1033-9396. Email: global@prescopus.com

*** Graduate student of the Department of Advocacy. Yaroslav Mudryi National Law University. Ukraine. ORCID ID: https://orcid.org/oooo-0002-2081-1201. Email: info@prescopus.com
}

Recibido el 14/04/2021 Aceptado el 02/06/2021 
690

Tetiana Vilchyk, Alla Sokolova y Tetiana Demchyna

Regulation of advocacy profession: global trends

\section{Regulación de la profesión de abogacía: tendencias globales}

\section{Resumen}

El objetivo del articulo consiste en analizar la regulación de la profesión de abogado y sus tendencias globales. Hay muchos tipos diferentes de reguladores a nivel mundial, y muchas fuentes y métodos diferentes de regulación. No existe un enfoque sencillo para establecer metas para regular la profesión de abogacía en diferentes sistemas legales. Aunque la autorregulación de la profesión de abogacía se considera la base para adherirse al estándar de su independencia, al mismo tiempo, los académicos reconocen la existencia de la teoría de la gestión de la abogacía. Para estudiar estos problemas, los autores realizaron un estudio comparativo de los modelos de regulación de la profesión de abogacía en el mundo en términos del cumplimiento de los estándares internacionales de independencia de la abogacía en diferentes jurisdicciones legales e hicieron algunas sugerencias para mejorar la regulación legal de la abogacía en Ucrania. Las fuentes empíricas para la investigación científica fueron documentos internacionales, decisiones judiciales, legislación nacional de Gran Bretaña, Canadá, Estados Unidos, Irlanda, Escocia, Australia y otros, y el trabajo de científicos. El artículo utiliza métodos científicos generales - dialéctica, análisis, síntesis, analogía, etc., y métodos especiales, particularmente el derecho comparado legal, histórico legal y formal.

Palabras clave: asociación de defensores; regulación de la defensa; independencia de la defensa; asociaciones autónomas de defensores; regulación de la abogacía.

\section{Introduction}

The independence and self-regulation of advocates are essential in ensuring the rule of law in any jurisdiction. Although advocacy in the modern world is based on the principle of self-organization of advocates and bar associations, there are few countries in the world where advocates are entirely self-regulated without any supervision, guidance, or restrictions from other sources, such as the executive, legislature, or judiciary (Bakaianova et al., 2019). In recent years, there has been increased interest in regulating the advocacy profession. The motivation of scholars and practitioners to discuss the independence of the bar and its ability to self-regulation is, to some extent is the result of regulatory changes in the legislation of countries such as England, Wales, Australia, New Zealand, in which governments have increased the involvement of non-lawyers in the regulation of advocacy profession and have adopted significant changes 
aimed at consumers of legal services (Djaburia, 2019; Gregory and Austin, 2019). Thus, at this time, it has become commonplace to talk about the relatively recent trend of transition from self-regulation of the advocacy profession to co-regulation. Based on the above, it is important to conduct a comparative legal study of the legislation governing the activities of bar associations in the world, as well as to make specific proposals to improve the legislation governing the activities of these bodies in Ukraine, which is the purpose of this work.

\section{The main functions of professional associations of advocates}

Bar associations are a unique form of public organization, officially recognized by law as a structure of civil society involved in law enforcement (Moiseeva, 2017). In most countries, governments have delegated reasonably broad powers to self-governing bar associations. They can control access to the profession (for example, by stipulating such access by membership in the organization, as well as by imposing requirements on such membership); have quasi-judicial powers (for example, disciplinary proceedings against their members); establish rules that sometimes have to be applied not only by their members but also by the courts and the public (e.g., professors of law in Croatia, provide legal advice and write legal opinions and are not allowed to become members of the Bar if they do not leave teaching and will not start a private practice). The most essential functions of a professional association include «corporate court» over those members of the community who have violated professional ethics. Many professions have a formal code of ethics, but relatively few have real mechanisms for tracking violations and applying sanctions. Thus, to some extent, advocacy association may have legislative, executive, and judicial prerogatives - and the more they exist, the more accountable they must be to society for the proper use of such prerogatives. The professional community of advocates' main functions includes social control (ethical norms and disciplinary practice) and socialization (exams and training) of members (Bakaianova et al., 2019; Zaborovskyy et al., 2020).

The solidarity between members of the profession is possible only in the presence of an association that provides, sometimes forcibly, commitment to the ideals of the profession. Any professional association, to have the right to speak on behalf of the whole profession, must get into its ranks all potential members who meet the criteria for admission to it. Not every association succeeds, but it must at least strive for completeness (Djaburia, 2019). The term "completeness" Merton means the ratio of current and potential members of the association. This indicator determines the authority of the association in a particular area of activity. If we turn to the advocacy profession in Ukraine, the whole history of its development 
is characterized by the struggle to achieve the full completeness of the professional association. For a long time, advocates did not have a single corporate organization. Although pre-revolutionary and Soviet times had councils of juries and Bar associations, they operated only at the regional level, were more formal, and were under state control. Only with the creation of bar self-government bodies in 2012, with the mandatory membership of each advocate, it became possible to talk about the introduction of a fullfledged professional association. However, advocates did not get a complete victory in the struggle for completeness because there were and continue to be groups of lawyers who are potentially able to enter the Bar but do not want to do so.

\section{Self-regulation of the advocacy profession based on the principle of independence}

The term "independence" of the advocacy profession is quite adequately defined in Recommendation (2000) 21 as "the freedom to pursue a profession without undue interference". Bar associations must have institutional independence, both legal and practical, from all external parties, including the government, other executive bodies, parliaments and external private interests. In particular, "the executive body of professional associations of advocates must be elected by its members and perform its functions without external interference" (principle 24). An advocate must be free - politically, economically, and intellectually - in their counseling and representation activities (Guess et al., 2018). It means that a lawyer must be independent of state and other government interests; he must not allow his independence to be undermined due to undue pressure from business partners (Moiseeva, 2017).

In its decision, the Supreme Court of Canada recognized the constitutional importance of the bar's independence for the functioning of the legal system and the protection of the rule of law. The court stated that "the bar's independence from the state in all its comprehensive manifestations is one of the characteristic features of the free profession." "Advocates should be free to represent citizens without fear or advantage in protecting their personal rights and civil freedoms from interference from any source, including public authorities."

Speaking about the self-regulation of the advocacy profession based on the principle of independence, one of the provisions underlying the rule of law is the right of advocates to be free from any influence that may interfere them from fulfilling their duties. Thus, according to the author, the rule of law is the basis of the independence of advocates (Moiseeva, 2017). Advocates' independence should include more than just freedom 
from state intervention. The formulation of the independence of the bar, in her opinion, is based on a special concept of ethical and legal unique duties of an advocate, which are quite contradictory. The dispute between pro-independence advocates and critics of such independence is essentially a dispute about the nature of advocates' professional and ethical responsibilities and not about the independence of bar associations (Zaborovskyy et al., 2020).

Since lawyers perform a public-law function of providing professional legal assistance, there is a need to ensure some control (i.e., change or cancellation of the result of an act) over advocates' activities and bodies of the bar and bar associations, which does not undermine the principle of independence of the bar (Gregory and Austin, 2019). The narrowing of state dictation sphere is a clear and undoubted trend in the development of democratic public institutions, including the bar. However, this trend cannot be unlimited. Even during the judicial reform in Russia in 1893, the state, by transferring disciplinary power to the state itself and not retaining the right to control its activities, would have no guarantee that advocates' misconduct would be prosecuted with due energy and impartiality; on the other hand, individuals entrusted with the protection of their rights to advocates will not be sure of the objectivity of the assessment of the abuse of the latter by their comrades (Zaborovskyy et al., 2020).

Furthermore, the advocates will find themselves in a difficult situation because their fate will be in colleagues' hands, burdened with personal likes and dislikes. A scholar proposes to recognize the existence of the theory of advocacy management, with which one cannot disagree. Thus, studying the problems of interaction between the bar and the state determines the dual nature of such management - corporate (self-government) and state. It should be added that the volume of implementation of such an element of the principle of independence of the bar as independence from the state increases proportionally to the expansion of self-government of the bar (Bakaianova et al., 2019).

\section{Regulation of the advocacy profession: concept}

The requirement of independence places responsibility not only on the bar association itself, but also on the executive and the legislature, which must respect that independence, refrain from inappropriate interference, adopt appropriate legislative and institutional guarantees and not violate them in practice (Gregory and Austin, 2019).

The concept of "regulation" (from the Latin regulo - rule) means ordering, adjusting, bringing something in line with something. To regulate is to determine the behavior of people and their teams, to direct its functioning 
and development, to give it certain limits, to purposefully organize it. The term "regulate" means to set boundaries, the scale of people's behavior, to bring stability, system, order to social relations and thus direct them in a certain direction. An important aspect in the formation of understanding of the essence of regulation are the traditions of a particular state, as well as scientific and theoretical traditions that set boundaries and determine the direction of legal regulation (Guess et al., 2018).

The regulatory process as a purposeful process that has one or more goals designed to change activities or behaviors ... often by limiting such behavior, encouraging its participants, or facilitating their activities from time to time, without which this activity or behavior would be impossible. As for the regulation of bar associations, it can be carried out not only in a general way (for example, by adopting legislation on their organization and activities), but also by resort to more detailed regulated actions, such as interaction of advocates with the clients, the court, the legal system. And while some of these actions may be regulated by additional normative provisions, which must also be followed, they must be assessed by the regulator also in terms of compliance with the law (Bakaianova et al., 2019).

\section{Methods of regulating the advocacy profession}

Provisions on advocates' legal regulations are contained in many different types of regulations. Examining this issue from a global perspective, some scholars classify these acts as follows: 1) legislation that may be specific to a particular profession (e.g., the legislation on advocacy in Canada, Australia or Germany legislation that is more widely used, (for example, the provisions of the US Bankruptcy Act applicable to advocates advising debtors, the British rules on money laundering, similar laws adopted in other jurisdictions 3) regulations adopted by bar associations (For example, in Germany the bar association has adopted mandatory regulations (Berufsordnung) concerning the advocacy profession (Rechstanwälte) on the basis of powers granted to it by federal law) (Dubal, 2017; Hatcher, 2019). It is necessary to add rules of conduct for advocates, which are called ethical rules or rules of professional conduct (Rules of conduct in U.S. states).

In some jurisdictions, primary regulators, such as the US Supreme Court, adopt these rules. In other cases, several regulation levels may be involved before these documents reach the organization that adopts the rules of conduct of the advocate. For example, the UK Legal Services Act 2007 established the Legal Services Council, which approved the Solicitors Regulatory Authority (SRA) as the primary regulator for advocates in England and Wales Professional and ethical standards for advocates in 
British Columbia, for instance, contained in the Law on Advocacy, the Rules of the Law Society and the Code of Professional Conduct, which determine the behavior of lawyers not only in legal practice but also in other areas, and also in court decisions and disciplinary decisions of the advocates association (Terry, 1997).

\section{Joint or supervisory regulation}

The simple equation that we would like to present is as follows: the less power the bar has, the higher its chances of being "independent"; the more prerogative and power it possesses, the stronger the need to apply specific external control mechanisms (i.e., supervision by state bodies - courts, ministries of justice) (Dodek and Alderson, 2017). Some alternative to selfregulation is joint regulation or supervisory regulation. The co-regulatory model provides that the right to complain about lawyers' actions may be shared between different regulators. In contrast, the oversight model may allow decisions taken by corporate bodies of bar associations to be appealed to an independent body. (Australia, England and Wales are examples of joint regulation of the advocacy profession, where two or more bodies share lawyers' supervision). This provision is not in conflict with international standards, which stipulate that bar associations may not act as a final instance in resolving certain issues of their activities. For example, decisions on disciplinary action against its members, the granting of permission to advocacy practice, "should be reviewed by an independent and impartial judicial body". In any case, such a doctrine of "subsidiarity" remains a potential obstacle to claims to the ideal "independence" and "autonomy" of corporate bodies of professional bar associations.

\section{Regulating the advocates profession in different jurisdictions}

The UK Legal Services Act of 2007 radically changed some aspects of advocacy regulation in this country. The most significant aspect of the structural changes is related to the creation of a regulatory body - the Legal Services Council, which is responsible for managing all legal entities that regulate the activities of English lawyers, providers, including barristers and solicitors (Cone III, 2007). The Legal Services Council has approved the Solicitors Regulatory Authority (SRA) as the primary regulator for advocates in England and Wales, the Bar Council and the Ombudsman's Legal Service. The Legal Services Council sets standards that govern the conduct of advocates, carries out "targeted regulation" that involves not only responding to specific breaches of advocates' professional obligations but also trying to avoid, detect, and correct circumstances that create a high 
risk of professional breaches. In particular, the Legal Services Council has the power to set requirements for approved regulators: to set targets for them and to take specific measures if such indicators are not met, and to act if the "act or omission" of an approved regulator has a negative impact on the achievement of the goals of the regulator (Dodek and Alderson, 2017).

At present, the Legal Services Council's efforts are focused on protecting the rights of consumers of these services. For example, in its annual report, the Legal Services Council includes a separate section "Regulation in the consumers' interest". Describing the activities of the regulatory authorities of England and Wales, it should be noted that the Board of the Bar Council includes not only advocates but also lawyers who are appointed rather than elected. At the same time, the number of non-lawyers tends to increase (Hatcher, 2019).

Although the American system protects the profession's independence, in the United States, constitutional requirements for the separation of powers have allowed state courts to establish inalienable power over professional regulation. The independent character of the Irish Bar is a fundamental value underlying the profession and has served the cause of justice for hundreds of years. The only limitation on the barrister's ability to act independently is The Code of Conduct for the Bar of Ireland. However, under the Legal Services Regulation Act 2015 in Ireland, the Legal Services Regulatory Authority consists of eleven members appointed by the Government of Ireland, and, following Part 2 of the Act, most of them should be non-professionals. (The exception is, in particular, that one candidate is appointed by the Bar Council and two by the Bar Association of Ireland). The body regulates the provision of legal services by practicing lawyers and provides support and improvement of standards for the provision of such services in the state. Its powers include, in particular, the consideration of complaints about the actions of advocates, the adoption of professional codes, the movement of practicing lawyers between the professions of solicitor and barrister (Hatcher, 2019).

As for the regulation of the legal profession in other countries, for example, in two Canadian provinces - British Columbia and Quebec, the activities of the bar - a provincial law organization - are controlled by certain government agencies and officials. For example, in British Columbia, the Office of the Ombudsman has the right to receive and deal with complaints regarding advocates, to deal with regulatory issues, and to issue recommendations "to address injustices." In Quebec, the legal profession's governing body is the Tribunal, which can review the decisions of provincial bar associations. However, this oversight is limited and does not include guidance on the internal management or policies of such organizations (Maharramli, 2020). 
At the same time, there are countries in the world that have generally departed from legal society's self-government model. For example, Australia did this in the late ' 90 . The Australian Bar Association is the national representative body of Australian lawyers. It does not take any part in the admission of advocates or their professional practice. And the bodies that allow admission to the profession are the admissions offices of lawyers (for example, in New Wales, Northern Territory), the Council of Legal Practice of Western Australia, other admissions bodies in the state or territory in which the candidate intends to practice (Parker, 2002).

Analyzing the differences between the regulation of advocates' activities in England and Wales and in Canada, it can be identified the following: 1) the regulatory bodies governing lawyers in England and Wales, that subordinate to the Legal Services Council, while in Quebec and British Columbia in most jurisdictions the bar is subject to oversight only through judicial review or amendment of legislation; 2) The Board of the Bar Council in England and Wales includes not only advocates but also non-lawyers who are appointed rather than elected. Furthermore, the number of non-lawyers is increasing. In Canada, the governing bodies of advocates association are elected and overwhelmingly consist of lawyers; 3) The Code of Conduct for Lawyers in England and Wales emphasizes customer service as a priority for an advocate's responsibilities. Although there have been a number of regulatory changes in Canada, the general emphasis has remained on the set of ethical obligations of the advocate rather than on consumer issues (Bromwich, 2018; Maharramli, 2020).

Besides, the misconduct of advocates in England and Wales is dealt with and authorized by a separate, well-paid regulatory body appointed by a judge of the Court of Appeal. In Canada, disciplinary cases are heard by advocacy associations in unpaid colleges in most provinces. In both jurisdictions, the regulatory structure is not subject to direct executive or legislative control, and the basics of regulation in these countries are based on similar principles.

\section{Objectives of the advocacy profession regulating}

The concept of "regulatory goals" has a growing interest in the theory of regulation. As for the Bar, this trend has emerged against the backdrop of global government interest in regulatory theory. Regulatory goals serve as a guide both for those who regulate the legal profession and those subject to a specific rule, goal. For example, the UK Legal Services Council is committed to achieving a variety of regulatory objectives, including: protecting and promoting the public interest, upholding the constitutional principle of the rule of law, improving access to justice, protecting and promoting consumer 
interests, and promoting competition in legal services, encouraging an independent, strong, diverse and effective advocacy profession, promotion, adherence and support of professional principles (Domberger and Sherr, 1989). These professional principles are defined as:

- independence and integrity of the advocate,

- maintaining appropriate standards of work,

- adequate protection of the client's interests,

- independence in the interests of justice,

- confidentiality.

The United Kingdom is not the only jurisdiction that has defined regulatory objectives. A number of jurisdictions have adopted regulatory targets for lawyers, and interest in this issue is growing: regulatory targets have been proposed among other countries for Australia, Ireland and India. Normative legal acts regulating the advocacy in the world usually do not define or clearly formulate this regulation's purposes. Although the lack of clear regulatory objectives is recognized as a global rule, there are some exceptions. For example, in several Canadian provinces, some provisions can be equated with regulatory objectives. In Ireland, the Legal Services Regulatory Authority must take into account the objectives of: (a) protecting and promoting the public interest, (b) supporting the proper and effective administration of justice, (c) protecting and promoting the interests of consumers concerning the provision of justice, (d) promoting competition in the provision of legal services in the state, (e) promoting an independent, strong and efficient legal profession, (f) adherence to professional principles. In 2010, Scotland passed a new law that includes regulatory objectives (Terry, 2013; Bodrunova, 2021). Canada is another example of a jurisdiction that has clearly articulated the goals of regulating advocacy. Interestingly, the British Columbia Law Society must protect the public interests, not the lawyers' interests it regulates.

As for the independence of the Bar, the United Kingdom speaks of the need to ensure "an independent, strong, diverse and effective legal profession". The British Columbia Bar Association states on its website that self-regulation is part of ensuring the independence of advocates. Many other Canadian provinces are calling for "the decency and honor of an advocate" as the basis of his independence. The purpose for which the Danish Bar and Law Society was established is, in particular, to protect the independence and integrity of advocates, ensuring the fulfillment of their responsibilities (Terry, 2013).

Thus, the requirement of independence of the Bar is reduced to individual protection of advocates in the exercise of their professional functions, and to collectively ensure that advocates have self-governing associations 
to protect their interests, which includes, inter alia, maintaining and strengthening of professional standards and independence of advocates. But this general rule has some exceptions.

\section{Independence of the bar vs independence of advocates}

As was noted, the bar's regulatory powers to address the rights and responsibilities of its members are quite significant in most jurisdictions. Thus, at least in some instances, the bar's independence can be seen as possible danger of uncontrolled and illegal decisions that may restrict or violate its members' rights and freedoms. In any case, even thelegal decisions of the independent bar are, in fact, a restriction on the independence of advocates - their behavior, their personal and professional position depend on the decisions of the professional organization. Thus, the independence of the bar as an organization, to some extent, contradicts the independence of advocates (at least those who are members of the association).

In our opinion, the bar's internal norms should also be subject to review for their constitutionality and legality. The reference to the "independence of the bar" cannot grant immunity to the bar in case of violation of the legal rights of its members and third parties. This position is in line with the caselaw of the European Court of Human Rights. Thus, the European Court of Human Rights has noted that the state is responsible for the actions and decisions of bar associations, as these entities are established by law and have a public function of monitoring advocates' compliance with the rules (Mowbray, 2005).

Lastly, in jurisdictions where there is no absolute advocacy monopoly (and most are), the functioning of corporate bar associations may affect the independence of other legal practitioners, who may, for example, claim to have more rights to decide matters of common interest.

Who is the main beneficiary of advocates independence?

The independence of the bar is not an end. This privilege is given to advocates to successfully perform the functions assigned to them by the state. The question arises: "Who is the main beneficiary of professional "independence" - the bar, advocates, the legal system, or society as a whole"? Commonly used terms - "independence of advocates" and "independence of the bar" - may indicate that those who are primarily entitled to "independence" are either private advocates or bar associations. However, as in the case of judicial independence, the very reason for the existence of such a "privilege" is the performance of a specific function. In the case of the judiciary's independence, such a function provides the conditions for a fair and impartial resolution of specific cases. In the case of the advocacy profession's independence, such a function should be the need to provide an environment in which everyone has the right to the best legal representation possible in any kind of legal proceedings. 
We noted in us researches that, based on the legal nature of the bar, the status of an advocate as a party to the proceedings and an integral part of the administration of justice, the primary duty of an advocate is to assist in the administration of justice. To carry out its functions, the bar must have the same independence as the judiciary, which is vital for the fair administration of justice, strengthening democracy, and the rule of law. "The advocacy profession is genetically related to the judiciary and cannot but be transformed after it". The ultimate goal of the independence of the bar is to achieve a system of justice that would properly promote the observance and protection of the rights of every person. Thus, the primary beneficiary of any professional "independence" is each individual citizen, as such "independence" is established and maintained in order to guarantee everyone an impartial, prompt, and accessible legal protection of appropriate quality. As stated in the Conclusions of the Multilateral Meeting on Judicial Public Policy of the Council of Europe, independence should not be seen as a privilege granted to judges but as a guarantee for citizens. Thus, the independence and responsibility of judges do not contradict each other (Greer and Williams, 2009; Maharramli, 2020). Only such criteria can be used to assess individual situations of "dependent" or "independent" associations of advocates, and only such changes of national legislation make sense.

\section{Opportunities of advocates associations to influence social processes}

There is an idea that the ruling elite in any society is faced with the need to control the means of violence. Due to the specifics of their professional functions, advocates on a daily basis in specific cases oppose (often alone) the state machine of criminal prosecution and must address the rule of law and limit the misuse of violence by law enforcement agencies. In authoritarian states, advocates can represent and defend the interests of the ruling elite and, in this regard, be an extension of the law enforcement system. However, in most cases, advocates, on the contrary, are opposing (Kazun and Yakovlev, 2017; Bodrunova, 2021).

The ability of advocates associations in any country to influence social processes is directly related to the professional community's level of development, the presence of strong bar associations, the level of their independence from law enforcement and government, the demand for legal services from the public and business. According to many studies, advocates, due to the importance of their social status and their professional competencies related to law enforcement, are often key actors in social reform (e.g., public administration reform in Israel, legal reform in China, regular political initiatives in the United States. The position of the 
advocates' community can be emphasized apolitical, but even in this case, it is able to have a significant impact on society through its professional activities (for example, by helping vulnerable groups) (Greer and Williams, 2009; Maharramli, 2020).

\section{Problems of bar self-government bodies functioning in Ukraine}

Turning back to the prospects for the evolution of the advocates' community in Ukraine, it should be noted that today the Ukrainian National Bar Association (UNBA) is the largest non-profit organization in Ukraine, which operates on the basis of a special law and the Statute, has an extensive regional network and a high degree of autonomy. In particular, the UNBA Charter stipulates that UNBA is an apolitical, autonomous, and independent organization (Hatcher, 2019; Maharramli, 2020), which has financial and organizational independence. The Ministry of Justice of Ukraine has no control over UNBA, or the authority to issue certificates to advocates, its functions in relation to UNBA are limited to issues related to free legal aid (Kazun and Yakovlev, 2017). At the same time, Ukraine has not yet got rid of the problem common throughout the post-Soviet space - the existence of good laws and poor practice of their application, which usually leads to a dysfunctional justice system and undermines reforms. Now, the legislation on advocacy in Ukraine, although it mostly meets international standards for the organization and activities of the bar, at the same time widely violated (with a tendency to increase) the rights of advocates and guarantees of their independence (Kazun and Yakovlev, 2017; Bodrunova, 2021).

The market for services provided by lawyers in Ukraine is decentralized and is not subject to control either by the state or by advocates' corporate governance. This way, the state cannot guarantee everyone the right to professional legal assistance established by Ukraine's Constitution. In the case of the adoption of the Law № 1013 of 29.09.2019 "On Amendments to the Constitution of Ukraine (concerning the abolition of the lawyer's monopoly)" there will be a need to change a large number of laws governing lawyers who are not advocates, in order for them to have the same status, same standards of conduct as advocates. Although, in our opinion, such a need exists regardless of the adoption or non-adoption of this draft law. According to the Special Rapporteur report on the Independence of Judges and Advocates of the United Nations, to ensure the integrity of the whole profession and the quality of legal services, it is desirable to create a single professional association governing the legal profession. (The "completeness" of the advocates' profession was discussed above) (Hatcher, 2019; Maharramli, 2020). 
In this regard, it should be added that in countries where there is no "advocates's monopoly" at all, there is a very effective mechanism for exercising the right of citizens to qualified legal aid, as the latter is provided by an appropriate set of measures related to the supervision of legal aid by advocates or the regulation of control mechanisms over the activities of lawyers who do not have an advocate's license (for example, in Finland). In Canada, there are 14 territorial and provincial law associations responsible for overseeing more than 120,000 lawyers (as of 2019). The national coordinating body of Canadian lawyers is the Federation of Legal Societies of Canada (FLSC) (Federation of Law Societies of Canada), responsible for developing national regulatory standards for the legal profession.

In Ukraine, advocates are not always able to fully participate in the process of discussing the legislation on advocacy. At the same time, as the Special Rapporteur noted in his communication on the independence of judges and lawyers addressed to the President of Ukraine, "legislation on the advocacy should be developed directly by the advocacy representatives. If Law establishes advocates' self-government, it is necessary to consult with it at all stages of the legislative process " (Bakaianova et al., 2019; Bodrunova, 2021). Although UNBA has a well-developed institutional structure that is functional and effective, the qualification and disciplinary process needs to be significantly refined to ensure that the bar, its institutions, and individual advocates can operate in accordance with international standards on the role of advocates. The admission process to the profession remains weak, somewhat outdated, and, as it turns out, is not free from deep-rooted corrupt practices, which undermines trust in the profession and weakens its independence. Besides, the inherited internal split in 2012 within the bar was not fully resolved (Bakaianova et al., 2019).

The problem of the advocates' associations functioning, and, above all, their independence is not entirely solved either in theoretical or practical layers. There is no theoretical consensus on absolute or partial independence of the bar and, accordingly, the development of criteria according to which state intervention in the bar's activities can be considered acceptable. The bar's principle of independence does not have an unambiguous understanding in the Law of Ukraine "On Advocacy and Advocacy activity" in terms of delimitation of powers to manage the bar between the state and the bar, which creates opportunities for arbitrary application of the Law. And lastly, since the most critical mission of advocates associations is to protect the interests of their members, there is a need to amend the Law of Ukraine "On Advocacy and Advocacy activity" to reflect the crucial role of corporate bar associations in achieving this goal. 


\section{Conclusions}

In most countries, states have delegated relatively broad powers to selfgoverning advocates' associations. They can have legislative, executive, and judicial prerogatives - and the more they have, the more accountable they must be to society for the proper use of such prerogatives. The narrowing of the state dictation sphere is a clear and undoubted trend in the development of democratic public institutions, including the bar. However, this trend cannot be unlimited. Since the bar performs a public law function of providing legal assistance, there is a need to ensure some control over its activities, which does not undermine the bar's principle of independence.

The concept of "regulatory goals" has a growing interest in the theory of regulation. Regulatory objectives serve as a guide for both those who regulate the legal profession and those covered by a particular rule. The bar activities are "regulated" by many different structures and different sources of law, including those that are directly related to the advocacy profession and those that have a broader application. Both different methods and different levels of regulation can be used. A specific alternative to selfregulation is joint regulation or supervisory regulation.

In recent times, the governments of some countries, on the one hand, have increased the participation of non-lawyers in the regulation of the advocacy profession and adopted significant changes aimed at consumers of legal services. On the other hand, there are countries in the world that have generally departed from the legal society's self-government model.

The independence of the bar as an organization, to some extent, contradicts the independence of advocates (at least those who are members of the association). The reference to the "independence of the bar" cannot grant immunity to the bar in case of violation of the legal rights of its members and third parties.

The ability of advocates associations in a country to influence social processes is directly related to the level of development of the professional community, the presence of strong bar associations in the country, the level of their independence from government, the development of professional communication. However, even in cases where the position of the legal community is apolitical, it can have a significant impact on society through its professional activities.

The market for services provided by lawyers in Ukraine is decentralized and is not subject to control either by the state or by advocates' corporate governance. In this way, the state cannot guarantee everyone the right to professional legal assistance established by the Constitution of Ukraine. Amendments proposed by the draft Law №1013 of September 29, 2019 (on the abolition of the advocate's monopoly), aimed at repealing the 
provisions of Article 131-2 of the Constitution of Ukraine on the exclusive representation of another person in court by an advocate will lead to a restriction of the constitutional right to professional legal assistance and, as a consequence, a violation of the essence of the fundamental right of everyone to judicial protection and a fair trial.

The legislative bodies of Ukraine should not only stand down from advocates participating in the process of discussing and adopting legislation on advocacy and advocacy activity but also be obliged to involve advocates in all stages of the legislative process. This provision should be implemented.

\section{Statement of conflict of interest}

The authors stated that there were no potential conflicts of interest regarding the research, authorship, and publication of this article.

\section{Financing}

The authors did not receive financial support for the research, authorship, and publication of this article.

\section{Bibliographic References}

BAKAIANOVA, Nana; SVYDA, Oleksii; DEMENCHUK, Maryna; DZHABURIYA, Olena; FOMINA, Oksana. 2019. "Advocacy of Ukraine under constitutional reform” In: Amazonia Investiga. Vol. 8, No. 22, pp. 574-579.

BROMWICH, Rebecca. 2018. “(Where Is) the Tipping Point for Governmental Regulation of Canadian Lawyers: Perhaps It Is in Paradise: Critically Assessing Regulation of Lawyer Involvement with Money Laundering After Canada-Attorney General-v Federation of Law Societies of Canada" In: Man. LJ. Vol. 41, No. 1, pp. 11-26.

BODRUNOVA, Svetlana S. 2021. "Information disorder practices in/ by contemporary Russia" In: The Routledge Companion to Media Disinformation and Populism. Routledge. Vol. 123, pp. 279-289.

CONE III, Sydney M. 2007. "International Legal Practice Involving England and New York Following Adoption of the United Kingdom Legal Services Act of 2007.” Nw. J. Int'l L. \& Bus. Vol. 28, pp. 400-415. 
DJABURIA, Elena. 2019. "Organizational forms of advocacy related to the creation of a legal entity: some problem aspects" In: Jurnalul juridic national: teorie şi practică, Vol. 36, No. 2-1, pp. 59-62.

DODEK, Adam; ALDERSON, Emily. 2017. "Risk Regulation for the Legal Profession” In: Alta. L. Rev. Vol. 55, pp. 608- 621.

DOMBERGER, Simon; SHERR Avrom. 1989. "The impact of competition on pricing and quality of legal services" In: International Review of Law and Economics. Vol. 9, No. 1, pp. 41-56.

DUBAL, Veena B. 2017. "The drive to precarity: A political history of work, regulation, \& labor advocacy in San Francisco's taxi \& Uber economies" Berkeley Journal of Employment and Labor Law. Vol. 38, No. 1, pp. 73135 .

GREGORY, Paul; AUSTIN, Zubin. 2019. "Pharmacists' lack of profession-hood: professional identity formation and its implications for practice" In: Canadian Pharmacists Journal/Revue des Pharmaciens du Canada. Vol. 152, No. 4, pp. 251-256.

GREER, Steven; WILLIAMS, Andrew. 2009. "Human rights in the Council of Europe and the EU: towards 'individual', 'constitutional'or “institutional'justice?” In: European Law Journal. Vol. 15, No. 4, pp. 462481.

GUESS, C. Dominik; TUASON, Ma Teresa; GÖLTENBOTH, Noemi; MIRONOVA, Anastasia. 2018. "Creativity through the eyes of professional artists in Cuba, Germany, and Russia" In: Journal of CrossCultural Psychology. Vol. 49, No. 2, pp. 261-289.

HATCHER, Mark. 2019. "The General Council of the Bar: a Note on its History" In: Legal Information Management. Vol. 19, No. 3, pp. 161-169.

KAZUN, Anton; YAKOVLEV, Andrei. 2017. "Who demands collective action in an imperfect institutional environment? A case study of the profession of advocates in Russia” In: Journal of Eurasian studies. Vol. 8, No. 1, pp. 60-71.

MAHARRAMLI, Etibar Vali. 2020. "Legal Framework for Free Legal Aid in Ukraine" In: Public Administration and Law Review. Vol. 2, pp. 52-62.

MOISEEVA, Ekaterina. 2017. "Plea bargaining in Russia: the role of defence attorneys and the problem of asymmetry" In: International Journal of Comparative and Applied Criminal Justice. Vol. 41, No. 3, pp. 163-184. 
Tetiana Vilchyk, Alla Sokolova y Tetiana Demchyna

706 Regulation of advocacy profession: global trends

MOWBRAY, Alastair. 2005. "The Creativity of the European Court of Human Rights" In: Human Rights Law Review. Vol. 5, No. 1, pp. 57-79.

PARKER, Christine. 2002. "Regulation of the ethics of Australian legal practice: autonomy and responsiveness" In: UNSWLJ. Vol. 25, pp. 649-676.

TERRY, Angela Dawson. 1997. "What's a Lawyer to Do: The Tension between Zealous Advocacy and the Model Rules of Professional Conduct” In: Am. J. Trial Advoc. Vol. 21, pp. 357-371.

TERRY, Laurel S. 2013. “Transnational Legal Practice (International)” In: Int'l Law. Vol. 47, No. 475-485.

ZABOROVSKYY, Viktor; BULETSA, Sibilla; BYSAGA, Yuriy; MANZYUK, Vasyl. 2020. "Compliance of guarantees of professional activity of ukrainian advocate with international standards of profession of advocate" In: The Lawyer Quarterly. Vol. 10, No. 2, pp. 170-187. 

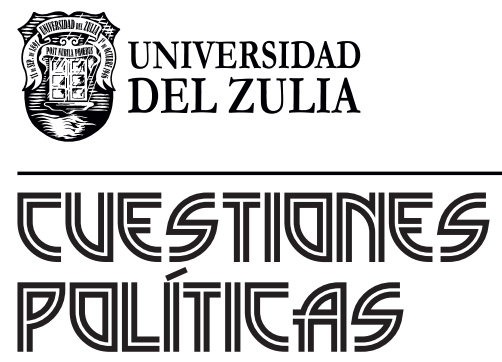

Vol.39 No 69

Esta revista fue editada en formato digital y publicada en julio de 2021, por el Fondo Editorial Serbiluz, Universidad del Zulia. Maracaibo-Venezuela 